\title{
Improvements in Body Composition, Cardiometabolic Risk Factors and Insulin Sensitivity with Trenbolone in Normogonadic Rats
}

Daniel G Donner ${ }^{\mathrm{a}}$, Belinda Beck ${ }^{\mathrm{b}}$, Andrew C Bulmer ${ }^{\mathrm{a}}$, Alfred K Lam ${ }^{\mathrm{c}}$, Eugene F Du Toit ${ }^{\mathrm{a}}$

\footnotetext{
${ }^{a}$ Heart Foundation Research Centre, Griffith Health Institute, Griffith University, Gold Coast, Queensland, Australia

${ }^{\mathrm{b}}$ School of Allied Health Sciences, Griffith University, Gold Coast, Queensland, Australia

${ }^{\mathrm{c}}$ Cancer Molecular Pathology, School of Medicine, Griffith Health Institute, Griffith University, Gold Coast, Queensland, Australia
}

Words: 4,524

\section{Corresponding Author}

Daniel G Donner

Office 2.25

Health Sciences Building (G05)

School of Medical Science

Griffith University

Southport, QLD, 4222

AUSTRALIA

$P h \quad$ (+61) 411377744

Fax (+61) 755528908

Email $\underline{\text { d.donner@griffith.edu.au }}$ 


\section{ABSTRACT}

Trenbolone (TREN) is used for anabolic growth-promotion in over 20 million cattle annually and continues to be misused for aesthetic purposes in humans. The current study investigated TREN's effects on body composition and cardiometabolic risk factors; and its tissue-selective effects on the cardiovascular system, liver and prostate. Male rats $(n=12)$ were implanted with osmotic infusion pumps delivering either cyclodextrin vehicle (CTRL) or $2 \mathrm{mg} / \mathrm{kg} / \mathrm{day}$ TREN for six weeks. Dual Energy X-ray Absorptiometry assessment of body composition; organ wet weights and serum lipid profiles; and insulin sensitivity were assessed. Cardiac ultrasound examinations were performed before in vivo studies assessed myocardial susceptibility to ischemia-reperfusion (I/R) injury. Circulating sex hormones and liver enzyme activities; and prostate and liver histology were examined. In six weeks, fat mass increased by $34 \pm 7 \%$ in CTRLs ( $\mathrm{p}<0.01$ ). Fat mass decreased by $37 \pm 6 \%$ and lean mass increased by $11 \pm 4 \%$ with TREN ( $p<0.05)$. Serum triglycerides, HDL and LDL were reduced by 62,57 and $78 \%(\mathrm{p}<0.05)$ respectively in TREN rats. Histological examination of the prostates from TREN-treated rats indicated benign hyperplasia associated with an increased prostate mass ( $149 \%$ compared to CTRLs, $\mathrm{p}<0.01$ ). No evidence of adverse cardiac or hepatic effects was observed. In conclusion, improvements in body composition, lipid profile and insulin sensitivity (key risk factors for cardiometabolic disease) were achieved with six week TREN treatment without evidence of adverse cardiovascular or hepatic effects that are commonly associated with traditional anabolic steroid misuse. Sex hormone suppression and benign prostate hyperplasia were confirmed as adverse effects of the treatment.

\section{KEYWORDS}

Trenbolone; selective androgen receptor modulator; fat loss; insulin sensitivity; androgenic anabolic steroid; cardiac 


\section{INTRODUCTION}

Trenbolone (TREN) is a selective androgen receptor modulator (SARM) not indicated for human use. Commonly referred to as 'designer steroids', most SARMs are modified analogues of male sex hormones, generally exhibiting more favourable and reduced adverse effects in vivo when compared to native androgens. [1,2] TREN's potential as a therapeutic alternative to testosterone has not translated into clinical practice with its clinical and veterinary use banned in some European countries.[3,4] Despite this, TREN continues to be used as an anabolic growth-promoter in over 20 million cattle annually [4, 5] and remains heavily misused by bodybuilders for body fat-reducing and body recompositioning purposes. $[6,7]$ Investigation into the therapeutic potential of TREN remains limited to applications in livestock and meat produce,[8-10] with few recent exceptions.[11-13] Emerging research has identified TREN as a potential substitute for testosterone in androgen replacement therapy in osteopathy; however comprehensive studies of its safety and more specific potential to reduce body fat and improve lipid profile and insulin sensitivity (key components of the metabolic syndrome and cardiometabolic risk)[14] remain elusive.

\section{Androgenic-anabolic Steroids}

Androgenic-anabolic steroid (AAS) misuse is an ever-growing public health concern, particularly in developed countries.[15-19] With the emergence of predominantly biased, non-scientific recommendations for AAS misuse published on the internet,[20] misinformation regarding AAS safety is no longer isolated within the gymnasiums of the Western world.[21, 22]

Testosterone (TEST) is the most abundant circulating androgen in healthy males and is responsible for the maintenance of numerous androgenic (male sex-specific) and anabolic processes. Selective androgen receptor modulators (SARMs) are a large group of synthetic 
male sex hormone analogues, some lacking the steroidal backbone entirely,[23] which exhibit a broad range of anabolic and androgenic potencies.[24] Relatively subtle modifications to the cholesterol backbone of the testosterone molecule can translate into significant changes to the SARM's binding affinity for members of the steroid receptor superfamily and the numerous enzymes capable of converting the SARM to other steroids. [25] Common redesigns of testosterone's molecular structure aim to reduce the SARMs' binding affinities for $5 \alpha$-reductase and aromatase, the enzymes responsible for the molecular bioconversion of testosterone to dihydrotestosterone (DHT) and estradiol (EST), respectively.

\section{Selective Androgen Receptor Modulators}

In order to influence the interaction between SARMs, receptors and enzymes, the chemical structure of the testosterone molecule can be modified by: 1) esterification at the $17 \beta$ hydroxyl group (increasing hydrophobicity); 2) alkylation at the $7 \alpha$-position (reducing $5 \alpha$ reductase binding affinity; or 3) strategic modification at any of either $\mathrm{C} 1, \mathrm{C} 2$, C9 or C11 carbons $[26,27]$ in order to achieve a range of therapeutic effects. [28]

Trenbolone (17ß-hydroxyestra-4,9,11-trien-3-one or TREN) is a 19-nor androgen with pronounced myotrophic and reduced androgenic potency compared to TEST. In comparison to TEST, TREN's trophic effects are reduced in tissues expressing the enzyme 5 $\alpha$-reductase [29] indicating either a lower affinity for this enzyme or an altered metabolic conversion resulting in reduced bioconversion to dihydrotestosterone (DHT). This is of particular benefit in prostatic tissue where $5 \alpha$-reductase is most notably expressed. [30, 31] Additionally, the removal of the methyl group at position 19 of the steroid backbone broadly reduces the susceptibility of 19-nor androgens to aromatisation. [26]

TREN's capacity for candidature in clinical trials is limited by the current paucity in the literature investigating its multi-system physiological effects. The most commonly assessed 
physiological effects in SARM research relate to those concerning the prostate, bone and skeletal muscle. These studies are almost always conducted in either: 1) orchiectomised animal models; or 2) clinical cases of idiopathic hypogonadic hypoandrogenism. Rarely is the therapeutic potential of SARMs evaluated in eugonadal/normogonadal individuals or animals.

The current study investigates the potential benefit and androgen-inherent limitations of treatment with the selective androgen receptor modulator TREN to improve body composition and metabolic status in healthy animals with a normal sex hormone profile.

\section{EXPERIMENTAL}

\section{Animal Care}

One week after arrival at the Griffith University animal facility, twelve male Wistar rats (12 weeks old/300grams) were allocated two animals to a cage. Rats were housed under PC2 conditions in an artificial 12-hour day/night lighting cycle at a constant temperature of $21^{\circ} \mathrm{C}$ (40\% humidity) and provided ad libitum access to fresh food (Meat Free Rat and Mouse Cubes, Specialty Feeds, Western Australia) and water. All animal work was approved and performed in accordance with the guidelines of the Animal Ethics Committee of Griffith University (MSC/01/11) and the Australian code of practice for the care and use of animals for scientific purposes. Following each surgical procedure, buprenorphine $(10 \mu \mathrm{g} / \mathrm{kg}$ per day, i.m.) and enrofloxacin (5mg/day, i.p.) were administered for the management of postoperative analgesia and to reduce the likelihood of post-operative infection, respectively.

\section{Androgen Therapy}

At 32 weeks of age, animals were randomly assorted into control (CTRL) and trenbolone treatment (TREN) groups. In preparation for implantation, animals were anaesthetised with $5 \%$ isoflurane in $100 \%$ medical grade $\mathrm{O}_{2}$ and sedation was maintained with $2.5 \%$ isoflurane 
for each $20 \pm 5$ min operation. Maintenance of anaesthesia was monitored by assessing the pedal withdrawal reflex at 5 min intervals. Alzet mini-osmotic infusion pumps (model 2004, Alza Corp., Palo Alto, CA, U.S.A.) were prepared with either vehicle (45\%w/v $2 \beta-$ hydroxypropyl cyclodextrin in Milli-Q $\mathrm{H}_{2} \mathrm{O}$ filtered to $0.45 \mu \mathrm{m}$ ) or $2 \mathrm{mg} / \mathrm{kg} /$ day trenbolone (Steraloids, USA) dissolved in vehicle and inserted subcutaneously in the interscapular space. TREN dosages (mg per 28-day implant) were calculated for each rat based on individual body weights measured on the day of each implantation. Implants released either vehicle or TREN for $28 \pm 1$ days before being replaced in order to achieve up to 8 weeks of continuous treatment.

\section{Body Composition Assessment}

Both immediately following pump implantation (at 32 weeks of age) and six weeks afterward, whole body Dual-energy X-ray Absorptiometry (DXA) (XR-36 Quickscan densitometer, software version 2.5.3a, Norland Medical Systems, Inc., USA, Host/Scanner: 4.2.4/2.3.1) scans were performed. Each scan was performed at a high resolution setting $(1.5 \times 1.5 \mathrm{~mm}$, speed of $6 \mathrm{~mm} / \mathrm{s})$ in "small animal mode". In order to perform the scans, rats were sedated with a dual preparation i.p. injection of $50 \mathrm{mg} / \mathrm{kg}$ ketamine (Ketamil, Troy Laboratories, Australia) and 3mg/kg xylazine (ilium xylazil-20, Troy Labrotories, Australia). All osmotic pump implants were excluded from the scan results using manufacturerinstructed software corrections to ensure there was no interference with tissue measurements.

Following animal sacrifice at the end of the study, retroperitoneal, epididymal and visceral fat pads were excised to quantify wet weight of the visceral fat depot in each animal. Subcutaneous fat mass was determined by calculating the difference between total fat mass (quantified by DXA) and the visceral fat mass. Additionally, the left ventricle of the hearts from each animal and each pair of testes were excised and weighed following sacrifice. 


\section{Cardiovascular Structure and Function Assessments}

Following six weeks of treatment (at 38 weeks of age), rats were anaesthetised $(2.5 \%$ isoflurane in $100 \%$ medical grade $\mathrm{O}_{2}, 1 \mathrm{~L} / \mathrm{min}$ ); and anterior and posterior left ventricular wall thicknesses were assessed throughout a typical cardiac cycle using ultrasound (Model 710b probe and Vevo 770, Visualsonics Inc., Ontario, Canada) with M- and B-mode analysis. Left ventricular volumes were derived using the algorithms provided by the manufacturer.

Stroke volume (SV) was derived from pulsed wave Doppler as the aortic volume time integral and cross sectional area product of the left ventricular outflow tract. Cardiac output (CO) was calculated as the product of heart rate and SV.

Due to the variability in body mass between the animals, both SV and CO are presented as both raw values and values corrected for body mass.

\section{Cardiac Tolerance to Ischemia-Reperfusion}

At 39 weeks of age, rats were anesthetised (sodium pentobarbital, $60 \mathrm{mg} / \mathrm{kg}$ i.p.), intubated and ventilated (Harvard Instruments, Model 683), and placed on an adjustable heating pad to maintain a core temperature of $36-37^{\circ} \mathrm{C}$, as monitored by rectal thermometer (Model 52II, Fluke Corporation, Everett, Western Australia). Maintenance of anaesthesia was monitored by assessing pedal withdrawal reflexes at 10 min intervals. A thoracotomy and reversible left anterior descending (LAD) coronary artery ligation were performed as outlined previously. [32] The LAD coronary artery was occluded for $45 \mathrm{~min}$ followed by $120 \mathrm{~min}$ of reperfusion upon ligature release. At the end of reperfusion hearts were rapidly excised and whole blood was collected from the thoracic cavity. Enzyme activity of cardiac-specific Creatine Kinase (CK-MB) was quantified using spectrophotometry (COBAS INTEGRA 400, Roche, Switzerland). 
At sacrifice, whole blood was collected from each animal and kept on ice at $4^{\circ} \mathrm{C}$ for 30 minutes before centrifugation at $1200 \mathrm{~g}$ for 10 minutes in order to isolate the serum for storage at $-80^{\circ} \mathrm{C}$.

Serum samples were thawed and prepared for multi-analyte analysis (COBAS INTEGRA 400, Roche, Switzerland). All analytes of interest (glucose, total cholesterol, HDL, LDL, triglycerides, total protein and albumin) were quantified within an hour of sample thawing. Concentrations of each analyte were quanititated using calibrator for automated systems/lipids (CFAS, CFASL) in addition to validation using commercially prepared quality control specimens (Preci Control Clin Chem. Multi 1 and 2; Roche Diagnostics, Switzerland).

Homeostatic Model Assessment of Insulin Resistance (HOMA-IR)

Serum insulin was quantified using a commercial homogenous time-resolved fluorescence (HTRF) kit (CISBIO, Codolet, France).

A routine assessment of impaired insulin sensitivity (i.e. insulin resistance) is the homeostatic model assessment of insulin resistance (HOMA-IR).[33, 34] HOMA-IR values were calculated using the formula: [Glucose $(\mathrm{mg} / \mathrm{dl}) x$ Serum Insulin $(\mu U / \mathrm{ml})] / 405$.

\section{Circulating Sex Hormone Quantitation}

Serum testosterone and estradiol concentrations were quantified using homogenous timeresolved fluorescence (HTRF) kits (CISBIO, France).

Liver Morphology and Function Assessment 
Immediately following sacrifice, a tissue biopsy was excised from the medial lobe of the liver for storage in formalin ( $10 \% \mathrm{v} / \mathrm{v}$ in $0.9 \%$ saline). One week following storage, samples were fixed and sectioned for haematoxylin and eosin (H \& E) staining and histological assessment.

Several circulating biomarkers of liver function were assessed in serum samples at sacrifice. Albumin and the activities of aspartate aminotransferase (AST), alanine aminotransferase (ALT) and alkaline phosphatase (ALP) were quantified (COBAS INTEGRA 400, Roche, Switzerland).

\section{Prostate Size and Morphology}

Immediately following sacrifice, prostates were surgically excised and stored in formalin ( $10 \% \mathrm{v} / \mathrm{v}$ in $0.9 \%$ saline). Prostates were later sectioned and prepared for $\mathrm{H} \& \mathrm{E}$ staining and histological assessment.

\section{RESULTS}

\section{Body Composition and Tissue Mass}

Six weeks following osmotic pump implantation, CTRL rats had experienced a $53.7 \pm 8.4 \mathrm{~g}$ $(8 \pm 1 \%)$ increase in body mass $(\mathrm{p}<0.01)$ (Table 1$)$. Although no significant difference was observed in lean mass ( $p>0.05)$, these animals exhibited a significant increase in fat mass of $64.7 \pm 13.1 \mathrm{~g}(34 \pm 7 \%)$ over the six week period $(\mathrm{p}<0.01)$ (Figure 1$)$.

No significant change in total body mass occurred over the six week period between scans in TREN-treated rats $(-31.7 \pm 13.5 \mathrm{~g}, \mathrm{p}>0.05)$ (Table 1). However, lean mass in TREN-treated rats increased by $49.7 \pm 15.7 \mathrm{~g}(11 \pm 4 \%)$ and fat mass decreased by $81.4 \pm 21.9 \mathrm{~g}(37 \pm 6 \%)$ over that period (for both comparisons $\mathrm{p}<0.05$ ) (Figure 1). 
The only between-group difference in body composition was a $143.3 \mathrm{~g}(54 \%)$ reduction in body fat content in TREN-treated rats at 38 weeks of age $(\mathrm{p}<0.01)$ (Table 1). Total body mass was not significantly different between groups at 38 weeks of age $(p>0.05)$ (Figure 2).

Fat distribution ratio (subcutaneous:visceral depot mass) was not significantly influenced by TREN treatment (4.40:1 \pm 0.43 vs. $5.29: 1 \pm 0.45$ in CTRLs, $p>0.05)$. Reductions in fat mass were similar between subcutaneous and visceral fat depots (55.7 and $43.7 \%$ respectively, $\mathrm{p}<0.01$ ) in TREN-treated animals (Figure 2).

No changes were observed between groups for lean mass; or wet weights of the left ventricle or testes (pair) (Table 1).

Lipid Profile and Homeostatic Model Assessment of Insulin Resistance (HOMA$I R)$

Serum total cholesterol, HDL and LDL were significantly lower in TREN rats at sacrifice decreasing by $62 \%, 57 \%$ and $78 \%$ respectively (all $\mathrm{p}<0.05$, Table 2 ). HDL:LDL ratio was significantly greater in TREN rats $(7.61: 1 \pm 0.53$ vs. $4.15: 1 \pm 1.19 \mathrm{mmol}$ in CTRL, $\mathrm{p}<0.05)$. Serum triglycerides were significantly lower in TREN animals decreasing by $51 \%$ compared to CTRLs $(\mathrm{p}<0.05)$. Serum total protein and glucose concentrations were similar between groups ( $p>0.05)$ (Table 2). However, serum insulin was significantly lower in TREN rats (38\% reduction) which translated into a significantly lower HOMA-IR value (1.88 \pm 0.11 vs. $3.30 \pm 0.23$ in CTRL, $\mathrm{P}<0.001$ ) (Figure 3).

\section{Circulating Sex Hormones}

Serum testosterone concentrations were significantly lower in TREN-treated rats $(35 \pm 11 \mathrm{vs}$. $168 \pm 18 \mathrm{ng} / \mathrm{dl}$ in CTRL, $\mathrm{p}<0.001)$. Similarly, serum estradiol concentrations were 
significantly reduced with TREN treatment $(2.7 \pm 0.4$ vs. $13.7 \pm 2.4 \mathrm{pg} / \mathrm{ml}$ in CTRL, $\mathrm{p}<0.01)$ (Figure 4).

\section{Cardiac Structure, Function and I/R tolerance}

No differences in anterior diastolic $(2.16 \pm 0.11$ vs. $2.55 \pm 0.34 \mathrm{~mm}, \mathrm{p}>0.05)$ or systolic (3.69 \pm 0.20 vs. $3.72 \pm 0.27$ in CTRL, $p>0.05)$ left ventricular wall thicknesses were observed in TREN animals. Similarly, posterior diastolic $(1.91 \pm 0.08$ vs. $1.88 \pm 0.13 \mathrm{~mm}, \mathrm{p}>0.05)$ and systolic (3.45 \pm 0.19 vs. $3.33 \pm 0.33$ in CTRL, $\mathrm{p}>0.05)$ wall thickness were comparable between groups. Both cardiac ejection fraction (EF\%) and fractional shortening (FS\%) were comparable between groups $(77.55 \pm 4.21$ vs. $76.32 \pm 7.53$ in CTRL; and $48.84 \pm 4.18$ vs. 49.51 \pm 8.19 in CTRL respectively, $\mathrm{p}>0.05)$.

The stroke volume (SV), raw cardiac output (CO) and CO corrected for body weight $(\mathrm{CO} / \mathrm{BW})$ were similar between groups ( $>>0.05)$ (Table 3).

Furthermore, no differences were observed in serum concentrations of CK-MB following in vivo myocardial infarction ( $\mathrm{p}>0.05)$ (Table 3$)$.

\section{Liver Structure and Function}

Hepatic tissue samples of TREN-treated animals showed similar morphology to those of CTRL rats. In both groups, liver histology revealed normal architecture with no remarkable features.

AST, ALT and ALP (liver enzymes); and albumin were similar between groups ( $\mathrm{p}>0.05)$ (Table 4).

Prostate Morphology and Size

Histological assessment of the prostates of CTRL rats revealed unremarkable glandular and stromal morphology (Figure 5). Prostates of TREN-treated rats revealed proliferative glands 
consistent with nodular hyperplasia. There was no definitive evidence of invasive carcinoma. Prostate mass at the end of treatment was $49 \%$ greater in TREN animals (909.32 \pm 75.25 vs. 609.23 $\pm 47.25 \mathrm{mg}$ in CTRL, $\mathrm{p}<0.01$ ) (Figure 5).

\section{DISCUSSION}

The current study investigated the phenotypic effects of the selective androgen receptor modulator (SARM) trenbolone (TREN) which included the assessment of body composition, biochemical markers of the metabolic syndrome (lipid profile and insulin sensitivity) and its effects on the heart (structure and function), liver (structure and functions) and prostate (size and structure). Although our data confirmed TREN's ability to reduce endogenous sex hormone production and promote the development of benign prostate hyperplasia, the observed potential benefits of TREN treatment may still justify its application in the treatment of obesity. This study demonstrates TREN's ability to reduce adiposity and its associated dyslipidaemia and insulin resistance/pre-diabetes.

\section{Phenotype Characterisation}

At the commencement of treatment with either vehicle or TREN, rats were 32 weeks of age which corresponds to approximately 29 years of age in humans. Rats were also sexually mature having reached sexual maturity at $\sim 6$ weeks of age.[35, 36]

Rats treated with TREN had significant reductions in adipose tissue (fat mass) and significantly less testosterone than CTRLs. It is likely that less substrate was available for conversion to estradiol via the aromatase enzyme, expressed most notably in adipose tissue, [11-13] explaining the additional reductions in circulating estradiol. Circulating DHT levels were likely to be reduced by a similar mechanism since the binding affinity of $5 \alpha$-reductase for TREN is substantially lower than that for testosterone. [30, 31] Although DHT levels were not quantified in the current study, circulating levels of both testosterone and estradiol 
were effectively reduced with TREN treatment, supporting the notion that circulating DHT was also reduced in TREN rats.

\section{Impact of Trenbolone on Body Composition}

Activation of the androgen receptor induces trophic effects in a variety of tissues, some of which are elicited at the stem cell level.[37]

Adipogenesis is partly mediated by the estrogen receptor alpha (ER $\alpha)$ expressed on preadipocytes.[38-40] The observed TREN-induced reductions in adipose tissue in the current study (Figure 1) may partly be explained by the reduced bioavailability of circulating estradiol in TREN-treated animals (Figure 4) and the subsequent reduced activation of the estrogen receptor in these tissues.

The androgen receptor (AR) is expressed on preadipocytes [41, 42] and androgens have been well-documented to reduce adiposity in vivo. They elicit these effects by inhibiting lipid uptake and stimulating lipolysis by increasing beta-adrenergic receptor expression [43] and independently decreasing adipocyte proliferation [44].

In humans, circulating androgen levels are inversely associated with abdominal obesity [45] and subsequent development of the Metabolic Syndrome.[46] These observations may provide an additional explanation for the decreased adiposity, especially visceral adiposity, observed in rats treated with TREN.

Androgens are well-known for their anabolic effects in skeletal muscle tissue. Myogenic changes are often observed with a concomitant reduction in adiposity, partly explained by the role of androgens in differentiation at the pluripotent stem cell level. Both testosterone and DHT regulate lineage determination in mesenchymal pluripotent cells, promoting commitment to the myogenic lineage and inhibiting commitment to the adipogenic 
lineage.[37] These mechanisms may partly explain the observations of improved body composition in the current study in response to TREN treatment (Table 1). Additionally, increases in metabolic demand due to increased skeletal muscle tissue are likely to limit adipocyte hypertrophy, largely irrespective of their cause. [47]

Conversely to our understanding of endocrine disruption in various animal models, observations by Finkelstein et al. (2013) recently identified a potentially critical role for estrogen in the reduction of adiposity during native androgen replacement therapy. [48] These findings suggest that longer term SARM treatment studies are required to evaluate the effects of sex hormone suppression associated with prolonged SARM treatment. These long term studies would also provide valuable insight into the interactions between the various sex hormones and their roles without the requirement for potent enzyme antagonism.

\section{Serum Lipid Profile Improvements}

Although observations from clinical studies of testosterone therapy in men suggest that it does not contribute to an atherogenic profile,[49] reports of atherosclerotic plaque formation with testosterone abuse remains controversial.[50-52]

Observations of fat loss are strongly associated with favourable changes in serum lipid levels, [53] especially in men.[54] The improvements in body composition conferred by TREN treatment in the current study are confirmed by the improvements in the lipid profile of these animals (i.e. reduced triglycerides, total cholesterol and improved HDL:LDL ratio).

\section{Improved Insulin Sensitivity}

The venous drainage of visceral adipose tissue via the hepatic portal circulation results in increased circulating free fatty acids (FFAs), which in turn increase production of glucose and triglycerides in the liver and other tissues. [55] Adipocytes and monocyte-derived 
macrophages additionally contribute to an adverse inflammatory profile, inhibiting insulin receptor-mediated signalling in various tissues [56], ultimately resulting in insulin resistance. [57]

In humans, visceral fat accumulation and subsequently elevated circulating triglyceride levels are also associated with the development of insulin resistance.[58] Conversely, caloric restriction-induced weight-loss in viscerally obese, non-diabetic men (fat mass reductions of 30\%) induces significant improvements in insulin sensitivity.[59]

The substantial reductions in adiposity of $37 \%$ observed in the current study (Figure 1) were closely associated with similar improvements in both fasting insulin and insulin sensitivity as assessed by the homeostatic model of insulin resistance (HOMA-IR) (Figure 3). These reductions are likely mediated via similar anti-inflammatory mechanisms. Therefore, TREN treatment in rats may confer anti-adipogenic and insulin-sensitising effects through similar mechanisms to those achieved by caloric restriction in human males.

\section{Absence of Cardiovascular Remodelling}

Anabolic-androgenic steroid abuse is associated with a range of cardiovascular pathologies.[60-62] Testosterone therapy decreases ejection fraction (EF) and increases left ventricular dimensions during diastole (dilitation of the LV).[63] More recent observations report acute myocardial inflammation, adversely affecting myocardial healing and remodelling following acute myocardial infarction.[64] Furthermore, androgen-related cardiac remodelling is also implicated in an increased risk of atrial fibrillation[65] and sudden death. $[66,67]$

These data suggest that testosterone is primarily responsible for the dysfunction observed in these studies. However, the role of testosterone's key androgenic metabolite, DHT has not been considered in these studies. The effect of testosterone administration on cardiovascular 
remodelling is highly dependent on $5 \alpha$-reductase activity and may partly be due to androgenic effects of DHT which would be expected to increase with testosterone therapy.[68]

The assumed reductions in DHT resulting from TREN treatment and its subsequent suppression of endogenous testosterone release may translate into the maintenance of normal cardiac structure and function in the presence of the exogenous androgen. No adverse changes were observed in cardiovascular structure or function in response to TREN treatment in the current study (Table 3).

Androgen receptors, present in cardiac myocytes of multiple species, including humans, mediate a hypertrophic response in the myocardium.[69] Despite TREN treatment's suppression of endogenous testosterone release, we did not observe reductions in heart weight or function which appears to be preserved by the TREN treatment.

\section{Maintained Cardiac Tolerance of I/R Injury}

Testosterone has been repeatedly implicated in the aetiology of sex-specific cardiovascular pathophysiology [70, 71] and an increased risk of cardiovascular events.[72, 73] However, imbalances between testosterone's metabolites (estradiol and DHT) may be responsible for the damage observed in both clinical cases of steroid abuse and ischaemia-reperfusion (I/R) studies in animals.

In intact (non-orchiectomised) male rats, acute exogenous testosterone administration elicits limited direct cardioprotective effect because it is rapidly converted to either estradiol or DHT via the LV-expressed enzymes aromatase and 5 $\alpha$-R respectively.[74] Enzymatic inhibition of aromatase however significantly increases myocardial damage induced by I/R insult.[74] In contrast, enzymatic inhibition of 5 $\alpha-\mathrm{R}$ significantly reduces myocardial damage while treatment with DHT increases myocardial damage,[74] conclusively implicating DHT 
as the metabolite responsible for myocardial damage elicited by exogenous testosterone treatment. Our study is the first to investigate the role of androgens on myocardial tolerance to $\mathrm{I} / \mathrm{R}$ in the relative absence of these testosterone metabolites.

Six week TREN treatment led to a significant reduction in circulating testosterone, simulating the orchiectomised phenotype. However, TREN treatment resulted in the maintenance of myocardial tolerance to ischemia/reperfusion as evidenced by lack of change in circulating CK-MB following the myocardial infarct. This is likely due to the low affinity of TREN for aromatase and $5 \alpha-\mathrm{R}$, resulting in neither an elevation in estradiol nor DHT respectively. In the absence of estradiol, this finding provides further support for the critical role for androgens (in this case, TREN) in the maintenance of cardiovascular tolerance to I/R.

However, since declining insulin sensitivity is also associated with impaired cardiac tolerance of $I / R,[75,76]$ the observed maintenance of ischaemic tolerance may be confounded by the observed improvements in insulin sensitisation, especially as the I/R studies were carried out in vivo with appropriately compensated serum lipids, glucose and insulin; a profile which is difficult to replicate ex vivo.[77]

\section{Absence of Hepatic Toxicity}

Testosterone, its analogues and precursors induce hepatic stress and pathology.[78-81] In the current study, circulating liver enzyme activities and serum albumin were assessed to establish whether TREN had adverse effects on liver function. Albumin (a marker indicative of liver function) as well as activities of AST, ALT and ALP (general markers of hepatic damage, which might be caused by various liver disorders or overt toxicity) were similar between CTRL and TREN groups ( $p>0.05)$ suggesting that chronic TREN treatment has no adverse effects in the livers of healthy rats. 
Hepatic histology of liver samples from both CTRL and TREN animals revealed unremarkable lobular architecture with no evidence of fatty changes, cirrhosis or malignancy.

\section{Suppression of Endogenous Sex Hormones}

Six week TREN treatment had no significant effect on testicular weight or tissue histology with no remarkable architecture change in either Sertoli or Leydig cells compared to CTRLs. However, a significant reduction in endogenous testosterone was observed in serum, likely attributed to negative feedback via the hypothalamic-pituitary-gonadal axis. Similar changes are observed with numerous steroidal androgen treatments,[82] however the observed maintenance of testicular mass is indicative of a potentially transient and subsequently reversible hypoandrogenic effect. The multi-system effects of long term sex hormone suppression may have consequences which do not present with short term treatment. Changes that may present include bone remodelling and changes in adiposity caused by long term estrogen suppression.[48] Further investigation is also needed to confirm whether there will be endocrine recovery from TREN therapy following treatment cessation.

\section{Prostate Effects}

In the adult, benign and malignant growth of the glandular prostate tissue is largely regulated by sex hormones. Moderate increases in circulating testosterone translate into pronounced hyperplastic effects in these tissues, $[83,84]$ exacerbated by the local expression of $5 \alpha-$ reductase and the subsequent reduction of testosterone to dihydrotestosterone (DHT). According to the Pitt's unified theory of prostate cancer,[85] androgen-induced prostate hyperplasia occurs in the absence of malignancy. Subsequently, the development of prostate cancer is primarily induced by and reliant on circulating estradiol, generated from testosterone by aromatase expressed in adipose and other tissues. 
Prostates were significantly heavier in TREN-treated rats (Figure 5). On histological examination, this macroscopic feature was confirmed to be due to nodular hyperplasia with no definite evidence of invasive carcinoma. The absence of malignancy is likely in part due to the significant reduction in circulating estradiol, secondary to the suppression of endogenous testosterone production (Figure 3).

In conclusion, $2 \mathrm{mg} / \mathrm{kg} /$ day TREN treatment of eugonadal rats improved body composition, lipid profile and insulin sensitivity without: 1) adverse cardiovascular effects or increasing myocardial susceptibility to I/R injury; and 2) compromised hepatic structure or function. Although endogenous testosterone levels were reduced with TREN treatment, no remarkable changes were seen in testicular size or tissue morphology. These changes are a possible consequence of testosterone suppression which is likely transient. Prostates from TRENtreated animals had evidence of hyperplasia without invasive carcinoma observed on histological examination. Further investigation into the comparative benefits conferred by trenbolone therapy relative to the current gold standard, testosterone, are well justified by these findings - particularly in relevant models of obesity and metabolic dysregulation.

\section{ACKNOWLEDGEMENTS}

The present study was financially supported by the Heart Foundation Research Centre, the Griffith Health Institute and the School of Medical Science, Griffith University, Australia. These funds were used to support the animal purchase and housing costs; and the collection, analysis and interpretation of data compiled in the current study.

We are also grateful for the invaluable contributions of technical support offered by Melissa Leung and Rossana Nogueira in processing high resolution histological and DXA images respectively for use in this study. 


\section{REFERENCES}

[1] Omwancha J, Brown TR. Selective androgen receptor modulators: in pursuit of tissue-selective androgens. Current opinion in investigational drugs. 2006;7:873-81.

[2] Thevis M, Schanzer W. Synthetic anabolic agents: steroids and nonsteroidal selective androgen receptor modulators. Handbook of experimental pharmacology. 2010:99-126.

[3] Stephany RW. Hormonal growth promoting agents in food producing animals. Handbook of experimental pharmacology. 2010:355-67.

[4] Schiffer B, Daxenberger A, Meyer K, Meyer HH. The fate of trenbolone acetate and melengestrol acetate after application as growth promoters in cattle: environmental studies. Environmental health perspectives. 2001;109:1145-51.

[5] Ankley GT, Jensen KM, Makynen EA, Kahl MD, Korte JJ, Hornung MW, et al. Effects of the androgenic growth promoter 17-beta-trenbolone on fecundity and reproductive endocrinology of the fathead minnow. Environmental toxicology and chemistry / SETAC. 2003;22:1350-60.

[6] Geraci MJ, Cole M, Davis P. New onset diabetes associated with bovine growth hormone and testosterone abuse in a young body builder. Human \& experimental toxicology. 2011;30:2007-12.

[7] Daniels JM, van Westerloo DJ, de Hon OM, Frissen PH. [Rhabdomyolysis in a bodybuilder using steroids]. Nederlands tijdschrift voor geneeskunde. 2006;150:1077-80.

[8] Cleale RM, Amodie D, Bechtol DT, Drouillard JS, Edmonds JD, Edmonds M, et al. Effects of estradiol benzoate and trenbolone acetate, alone or in combination at dose levels present in Synovex Choice, on performance by feedlot heifers. Journal of animal science. 2013;91:970-7.

[9] Bryant TC, Engle TE, Galyean ML, Wagner JJ, Tatum JD, Anthony RV, et al. Effects of ractopamine and trenbolone acetate implants with or without estradiol on growth performance, carcass characteristics, adipogenic enzyme activity, and blood metabolites in feedlot steers and heifers. Journal of animal science. 2010;88:4102-19.

[10] MacNeil JD, Reid J, Fedeniuk RW. Distribution of trenbolone residues in liver and various muscle groups of heifers that received multiple implants at the recommended site of application. Journal of AOAC International. 2008;91:670-4.

[11] McCoy SC, Yarrow JF, Conover CF, Borsa PA, Tillman MD, Conrad BP, et al. 17beta-Hydroxyestra4,9,11-trien-3-one (Trenbolone) preserves bone mineral density in skeletally mature orchiectomized rats without prostate enlargement. Bone. 2012;51:667-73.

[12] Yarrow JF, Conover CF, McCoy SC, Lipinska JA, Santillana CA, Hance JM, et al. 17betaHydroxyestra-4,9,11-trien-3-one (trenbolone) exhibits tissue selective anabolic activity: effects on muscle, bone, adiposity, hemoglobin, and prostate. American journal of physiology Endocrinology and metabolism. 2011;300:E650-60.

[13] Yarrow JF, McCoy SC, Borst SE. Tissue selectivity and potential clinical applications of trenbolone (17beta-hydroxyestra-4,9,11-trien-3-one): A potent anabolic steroid with reduced androgenic and estrogenic activity. Steroids. 2010;75:377-89.

[14] Reaven P. Metabolic syndrome. Journal of insurance medicine. 2004;36:132-42.

[15] Handelsman DJ, Gupta L. Prevalence and risk factors for anabolic-androgenic steroid abuse in Australian high school students. International journal of andrology. 1997;20:159-64.

[16] Talih F, Fattal O, Malone D, Jr. Anabolic steroid abuse: psychiatric and physical costs. Cleveland Clinic journal of medicine. 2007;74:341-4, 6, 9-52.

[17] Brower KJ. Anabolic steroid abuse and dependence. Current psychiatry reports. 2002;4:377-87. 
[18] Tahtamouni LH, Mustafa NH, Alfaouri AA, Hassan IM, Abdalla MY, Yasin SR. Prevalence and risk factors for anabolic-androgenic steroid abuse among Jordanian collegiate students and athletes. European journal of public health. 2008;18:661-5.

[19] Brower KJ. Anabolic steroid abuse and dependence in clinical practice. The Physician and sportsmedicine. 2009;37:131-40.

[20] Clement CL, Marlowe DB, Patapis NS, Festinger DS, Forman RF. Nonprescription steroids on the Internet. Substance use \& misuse. 2012;47:329-41.

[21] Santos AM, da Rocha MS, da Silva MF. Illicit use and abuse of anabolic-androgenic steroids among Brazilian bodybuilders. Substance use \& misuse. 2011;46:742-8.

[22] Tripathi A, Tekkalaki B, Saxena S, Dandu H. latrogenic dependence of anabolic-androgenic steroid in an Indian non-athletic woman. BMJ case reports. 2014;2014.

[23] Gao W, Dalton JT. Expanding the therapeutic use of androgens via selective androgen receptor modulators (SARMs). Drug discovery today. 2007;12:241-8.

[24] Alvarez-Ginarte YM, Montero-Cabrera LA, de la Vega JM, Noheda-Marin P, Marrero-Ponce $Y$, Ruiz-Garcia JA. Anabolic and androgenic activities of 19-nor-testosterone steroids: QSAR study using quantum and physicochemical molecular descriptors. The Journal of steroid biochemistry and molecular biology. 2011;126:35-45.

[25] Fragkaki AG, Angelis YS, Koupparis M, Tsantili-Kakoulidou A, Kokotos G, Georgakopoulos C. Structural characteristics of anabolic androgenic steroids contributing to binding to the androgen receptor and to their anabolic and androgenic activities. Applied modifications in the steroidal structure. Steroids. 2009;74:172-97.

[26] Haendler B, Cleve A. Recent developments in antiandrogens and selective androgen receptor modulators. Molecular and cellular endocrinology. 2012;352:79-91.

[27] Kicman AT. Pharmacology of anabolic steroids. British journal of pharmacology. 2008;154:50221.

[28] Negro-Vilar A. Selective androgen receptor modulators (SARMs): a novel approach to androgen therapy for the new millennium. The Journal of clinical endocrinology and metabolism. 1999;84:3459-62.

[29] Wilson VS, Lambright C, Ostby J, Gray LE, Jr. In vitro and in vivo effects of 17beta-trenbolone: a feedlot effluent contaminant. Toxicological sciences : an official journal of the Society of Toxicology. 2002;70:202-11.

[30] Gruntmanis $U$. The role of 5alpha-reductase inhibition in men receiving testosterone replacement therapy. JAMA. 2012;307:968-70.

[31] Azzouni F, Godoy A, Li Y, Mohler J. The 5 alpha-reductase isozyme family: a review of basic biology and their role in human diseases. Adv Urol. 2012;2012:530121.

[32] Clark C, Smith W, Lochner A, du Toit EF. The effects of gender and obesity on myocardial tolerance to ischemia. Physiological research / Academia Scientiarum Bohemoslovaca. 2011;60:291301.

[33] Matthews DR, Hosker JP, Rudenski AS, Naylor BA, Treacher DF, Turner RC. Homeostasis model assessment: insulin resistance and beta-cell function from fasting plasma glucose and insulin concentrations in man. Diabetologia. 1985;28:412-9.

[34] Usui C, Asaka M, Kawano H, Aoyama T, Ishijima T, Sakamoto S, et al. Visceral fat is a strong predictor of insulin resistance regardless of cardiorespiratory fitness in non-diabetic people. J Nutr Sci Vitaminol (Tokyo). 2010;56:109-16. 
[35] Sengupta P. The Laboratory Rat: Relating Its Age With Human's. International journal of preventive medicine. 2013;4:624-30.

[36] Quinn R. Comparing rat's to human's age: how old is my rat in people years? Nutrition. 2005;21:775-7.

[37] Ray R, Novotny NM, Crisostomo PR, Lahm T, Abarbanell A, Meldrum DR. Sex steroids and stem cell function. Molecular medicine. 2008;14:493-501.

[38] Hong L, Colpan A, Peptan IA. Modulations of 17-beta estradiol on osteogenic and adipogenic differentiations of human mesenchymal stem cells. Tissue engineering. 2006;12:2747-53.

[39] Joyner JM, Hutley L, Cameron DP. Estrogen receptors in human preadipocytes. Endocrine. 2001;15:225-30.

[40] Shinozaki S, Chiba T, Kokame K, Miyata T, Ai M, Kawakami A, et al. Site-specific effect of estradiol on gene expression in the adipose tissue of ob/ob mice. Hormone and metabolic research = Hormon- und Stoffwechselforschung = Hormones et metabolisme. 2007;39:192-6.

[41] Xu X, De Pergola G, Bjorntorp P. The effects of androgens on the regulation of lipolysis in adipose precursor cells. Endocrinology. 1990;126:1229-34.

[42] Dieudonne MN, Pecquery R, Boumediene A, Leneveu MC, Giudicelli Y. Androgen receptors in human preadipocytes and adipocytes: regional specificities and regulation by sex steroids. The American journal of physiology. 1998;274:C1645-52.

[43] De Pergola G. The adipose tissue metabolism: role of testosterone and dehydroepiandrosterone. Int J Obes Relat Metab Disord. 2000;24 Suppl 2:S59-63.

[44] James RG, Krakower GR, Kissebah AH. Influence of androgenicity on adipocytes and precursor cells in female rats. Obesity research. 1996;4:463-70.

[45] Gapstur SM, Gann PH, Kopp P, Colangelo L, Longcope C, Liu K. Serum androgen concentrations in young men: a longitudinal analysis of associations with age, obesity, and race. The CARDIA male hormone study. Cancer epidemiology, biomarkers \& prevention : a publication of the American Association for Cancer Research, cosponsored by the American Society of Preventive Oncology. 2002;11:1041-7.

[46] Maggio M, Lauretani F, Ceda GP, Bandinelli S, Basaria S, Ble A, et al. Association between hormones and metabolic syndrome in older Italian men. Journal of the American Geriatrics Society. 2006;54:1832-8.

[47] Akasaki Y, Ouchi N, Izumiya Y, Bernardo BL, Lebrasseur NK, Walsh K. Glycolytic fast-twitch muscle fiber restoration counters adverse age-related changes in body composition and metabolism. Aging cell. 2014;13:80-91.

[48] Finkelstein JS, Lee H, Burnett-Bowie SA, Pallais JC, Yu EW, Borges LF, et al. Gonadal steroids and body composition, strength, and sexual function in men. N Engl J Med. 2013;369:1011-22.

[49] Roberts CK, Chen BH, Pruthi S, Lee ML. Effects of varying doses of testosterone on atherogenic markers in healthy younger and older men. American journal of physiology Regulatory, integrative and comparative physiology. 2014;306:R118-23.

[50] Garevik N, Strahm E, Garle M, Lundmark J, Stahle L, Ekstrom L, et al. Long term perturbation of endocrine parameters and cholesterol metabolism after discontinued abuse of anabolic androgenic steroids. The Journal of steroid biochemistry and molecular biology. 2011;127:295-300.

[51] Cohen LI, Hartford CG, Rogers GG. Lipoprotein (a) and cholesterol in body builders using anabolic androgenic steroids. Medicine and science in sports and exercise. 1996;28:176-9. 
[52] Webb OL, Laskarzewski PM, Glueck CJ. Severe depression of high-density lipoprotein cholesterol levels in weight lifters and body builders by self-administered exogenous testosterone and anabolicandrogenic steroids. Metabolism: clinical and experimental. 1984;33:971-5.

[53] Leenen R, van der Kooy K, Meyboom S, Seidell JC, Deurenberg P, Weststrate JA. Relative effects of weight loss and dietary fat modification on serum lipid levels in the dietary treatment of obesity. Journal of lipid research. 1993;34:2183-91.

[54] Leenen R, van der Kooy K, Droop A, Seidell JC, Deurenberg P, Weststrate JA, et al. Visceral fat loss measured by magnetic resonance imaging in relation to changes in serum lipid levels of obese men and women. Arteriosclerosis and thrombosis : a journal of vascular biology / American Heart Association. 1993;13:487-94.

[55] Eckel RH, Grundy SM, Zimmet PZ. The metabolic syndrome. Lancet. 2005;365:1415-28.

[56] Samuel VT, Liu ZX, Qu X, Elder BD, Bilz S, Befroy D, et al. Mechanism of hepatic insulin resistance in non-alcoholic fatty liver disease. The Journal of biological chemistry. 2004;279:32345-53.

[57] Neuschwander-Tetri BA, Caldwell SH. Nonalcoholic steatohepatitis: summary of an AASLD Single Topic Conference. Hepatology. 2003;37:1202-19.

[58] Katsuki A, Sumida Y, Urakawa H, Gabazza EC, Murashima S, Maruyama N, et al. Increased visceral fat and serum levels of triglyceride are associated with insulin resistance in Japanese metabolically obese, normal weight subjects with normal glucose tolerance. Diabetes care. 2003;26:2341-4.

[59] Bruun JM, Verdich C, Toubro S, Astrup A, Richelsen B. Association between measures of insulin sensitivity and circulating levels of interleukin-8, interleukin-6 and tumor necrosis factor-alpha. Effect of weight loss in obese men. European journal of endocrinology / European Federation of Endocrine Societies. 2003;148:535-42.

[60] Fanton L, Belhani D, Vaillant F, Tabib A, Gomez L, Descotes J, et al. Heart lesions associated with anabolic steroid abuse: comparison of post-mortem findings in athletes and norethandroloneinduced lesions in rabbits. Experimental and toxicologic pathology : official journal of the Gesellschaft fur Toxikologische Pathologie. 2009;61:317-23.

[61] Urhausen A, Albers T, Kindermann W. Are the cardiac effects of anabolic steroid abuse in strength athletes reversible? Heart. 2004;90:496-501.

[62] Vanberg P, Atar D. Androgenic anabolic steroid abuse and the cardiovascular system. Handbook of experimental pharmacology. 2010:411-57.

[63] Cavasin MA, Sankey SS, Yu AL, Menon S, Yang XP. Estrogen and testosterone have opposing effects on chronic cardiac remodeling and function in mice with myocardial infarction. American journal of physiology Heart and circulatory physiology. 2003;284:H1560-9.

[64] Cavasin MA, Tao ZY, Yu AL, Yang XP. Testosterone enhances early cardiac remodeling after myocardial infarction, causing rupture and degrading cardiac function. American journal of physiology Heart and circulatory physiology. 2006;290:H2043-50.

[65] Lau DH, Stiles MK, John B, Shashidhar, Young GD, Sanders P. Atrial fibrillation and anabolic steroid abuse. International journal of cardiology. 2007;117:e86-7.

[66] Fineschi V, Riezzo I, Centini F, Silingardi E, Licata M, Beduschi G, et al. Sudden cardiac death during anabolic steroid abuse: morphologic and toxicologic findings in two fatal cases of bodybuilders. International journal of legal medicine. 2007;121:48-53.

[67] Sullivan ML, Martinez CM, Gallagher EJ. Atrial fibrillation and anabolic steroids. The Journal of emergency medicine. 1999;17:851-7. 
[68] Tivesten A, Bollano E, Nystrom HC, Alexanderson C, Bergstrom G, Holmang A. Cardiac concentric remodelling induced by non-aromatizable (dihydro-)testosterone is antagonized by oestradiol in ovariectomized rats. The Journal of endocrinology. 2006;189:485-91.

[69] Marsh JD, Lehmann MH, Ritchie RH, Gwathmey JK, Green GE, Schiebinger RJ. Androgen receptors mediate hypertrophy in cardiac myocytes. Circulation. 1998;98:256-61.

[70] Du Toit EF, Rossouw E, Van Rooyen J, Lochner A. Proposed mechanisms for the anabolic steroidinduced increase in myocardial susceptibility to ischaemia/reperfusion injury. Cardiovascular journal of South Africa : official journal for Southern Africa Cardiac Society [and] South African Society of Cardiac Practitioners. 2005;16:21-8.

[71] Chung CC, Kao YH, Chen YJ, Chen YJ. Androgen modulates cardiac fibrosis contributing to gender differences on heart failure. The aging male : the official journal of the International Society for the Study of the Aging Male. 2013;16:22-7.

[72] Schooling CM, Cowling BJ. Testosterone therapy and cardiovascular events. Nature reviews Endocrinology. 2013;9:438.

[73] Higgins JP, Heshmat A, Higgins CL. Androgen abuse and increased cardiac risk. Southern medical journal. 2012;105:670-4.

[74] Rubio-Gayosso I, Ramirez-Sanchez I, Ita-Islas I, Ortiz-Vilchis P, Gutierrez-Salmean G, Meaney A, et al. Testosterone metabolites mediate its effects on myocardial damage induced by ischemia/reperfusion in male Wistar rats. Steroids. 2013;78:362-9.

[75] Wensley I, Salaveria K, Bulmer AC, Donner DG, du Toit EF. Myocardial structure, function and ischaemic tolerance in a rodent model of obesity with insulin resistance. Experimental physiology. 2013;98:1552-64.

[76] Donner D, Headrick JP, Peart JN, du Toit EF. Obesity improves myocardial ischaemic tolerance and RISK signalling in insulin-insensitive rats. Disease models \& mechanisms. 2013;6:457-66.

[77] du Toit EF, Smith W, Muller C, Strijdom H, Stouthammer B, Woodiwiss AJ, et al. Myocardial susceptibility to ischemic-reperfusion injury in a prediabetic model of dietary-induced obesity. American journal of physiology Heart and circulatory physiology. 2008;294:H2336-43.

[78] Granados J, Gillum TL, Christmas KM, Kuennen MR. Prohormone supplement 3b-hydroxy-5aandrost-1-en-17-one enhances resistance training gains but impairs user health. Journal of applied physiology. 2013.

[79] Stimac D, Milic S, Dintinjana RD, Kovac D, Ristic S. Androgenic/Anabolic steroid-induced toxic hepatitis. Journal of clinical gastroenterology. 2002;35:350-2.

[80] Pais-Costa SR, Lima OA, Soares AF. Giant hepatic adenoma associated with anabolic-androgenic steroid abuse: case report. Arquivos brasileiros de cirurgia digestiva : $A B C D=$ Brazilian archives of digestive surgery. 2012;25:180-2.

[81] Martin NM, Abu Dayyeh BK, Chung RT. Anabolic steroid abuse causing recurrent hepatic adenomas and hemorrhage. World journal of gastroenterology : WJG. 2008;14:4573-5.

[82] Tan RS, Scally MC. Anabolic steroid-induced hypogonadism--towards a unified hypothesis of anabolic steroid action. Med Hypotheses. 2009;72:723-8.

[83] Vargas RA, Oliveira LP, Frankenfeld S, de Souza DB, Costa WS, Favorito LA, et al. The prostate after administration of anabolic androgenic steroids: a morphometrical study in rats. International braz j urol : official journal of the Brazilian Society of Urology. 2013;39:675-82.

[84] Borst SE, Lee JH, Conover CF. Inhibition of 5alpha-reductase blocks prostate effects of testosterone without blocking anabolic effects. American journal of physiology Endocrinology and metabolism. 2005;288:E222-7. 
[85] Pitts WR, Jr. Validation of the Pitts unified theory of prostate cancer, late-onset hypogonadism and carcinoma: the role of steroid 5alpha-reductase and steroid aromatase. BJU international. 2007;100:254-7. 


\section{TABLES}

Table 1. Body and Tissue Mass

\begin{tabular}{|c|c|c|c|c|c|c|c|}
\hline & & $\frac{\text { CTRL }}{(n=6)}$ & & & $\frac{\text { TREN }}{(n=6)}$ & & \multirow[b]{2}{*}{$\begin{array}{l}\text { Between- } \\
\text { group } \\
\text { comparison } \\
\text { (p-value) }\end{array}$} \\
\hline & $\begin{array}{c}\text { Initial } \\
\text { (age } \\
\text { 32wks) }\end{array}$ & $\begin{array}{c}\text { Final } \\
\text { (age 38wks) }\end{array}$ & $\begin{array}{c}\text { Paired } \\
\text { comparison } \\
\text { (p-value) }\end{array}$ & $\begin{array}{c}\text { Initial } \\
\text { (age } \\
\text { 32wks) }\end{array}$ & $\begin{array}{c}\text { Final } \\
\text { (age 38wks) }\end{array}$ & $\begin{array}{c}\text { Paired } \\
\text { comparison } \\
\text { (p-value) }\end{array}$ & \\
\hline Body & & & & & & & \\
\hline $\begin{array}{l}\text { Mass (g) } \\
\text { Fat }\end{array}$ & $668.9 \pm 31.7$ & $722.6 \pm 37.9$ & 0.001 & $655.3 \pm 26.9$ & $623.6 \pm 22.4$ & 0.079 & 0.062 \\
\hline $\begin{array}{l}\text { Mass (g) } \\
\text { Lean }\end{array}$ & $201.9 \pm 27.2$ & $266.6 \pm 33.5$ & 0.004 & $204.7 \pm 26.7$ & $123.3 \pm 5.5$ & 0.021 & 0.004 \\
\hline $\begin{array}{r}\text { Mass (g) } \\
\text { Left }\end{array}$ & $467.1 \pm 12.5$ & $456.0 \pm 15.9$ & 0.434 & $450.6 \pm 12.3$ & $500.3 \pm 18.3$ & 0.034 & 0.099 \\
\hline $\begin{array}{r}\text { Ventricle } \\
(\mathrm{mg})\end{array}$ & - & $1312.8 \pm 49.7$ & - & - & $1310.7 \pm 147.3$ & - & 0.989 \\
\hline $\begin{array}{r}\text { Testes } \\
(\mathrm{mg})\end{array}$ & - & $3827.3 \pm 94.1$ & - & - & $3755.3 \pm 100.2$ & - & 0.651 \\
\hline
\end{tabular}


Table 2. Final Serum Profile

$\begin{array}{cccc} & \frac{\text { CTRL }}{(\boldsymbol{n}=\mathbf{5})} & \frac{\underline{T R E N}}{(\boldsymbol{n}=\mathbf{5})} & \boldsymbol{p} \text {-value } \\ \text { Total Cholesterol }(\mathbf{m M}) & 1.64 \pm 0.36 & 0.63 \pm 0.04 & 0.025 \\ \text { HDL }(\mathbf{m M}) & 1.30 \pm 0.24 & 0.55 \pm 0.02 & 0.014 \\ \text { LDL }(\mathbf{m M}) & 0.37 \pm 0.11 & 0.08 \pm 0.01 & 0.035 \\ \text { Triglycerides }(\mathbf{m M}) & 1.18 \pm 0.20 & 0.58 \pm 0.15 & 0.041 \\ \text { Total Protein }(\mathbf{g} / \mathbf{L}) & 26.08 \pm 0.73 & 26.05 \pm 1.00 & 0.979 \\ \text { Glucose }(\mathbf{m g} / \mathbf{d l}) & 110.93 \pm 10.42 & 90.33 \pm 5.73 & 0.137 \\ \text { Insulin }(\boldsymbol{\mu I U} / \mathbf{m l}) & 13.79 \pm 1.72 & 8.53 \pm 0.69 & 0.017\end{array}$

HDL - high density lipoprotein, LDL - low density lipoprotein 
Table 3. Cardiac Structure, Function and Measure of Post-ischaemic Damage

$\frac{\text { CTRL }}{(n=5)} \quad \frac{\text { TREN }}{(n=5)} \quad p$-value

Dimensions (mm)

\begin{tabular}{|c|c|c|c|c|}
\hline & Anterior Wall - Diastole & $2.55 \pm 0.34$ & $2.16 \pm 0.11$ & 0.308 \\
\hline & Anterior Wall -Systole & $3.72 \pm 0.27$ & $3.69 \pm 0.20$ & 0.935 \\
\hline & Posterior Wall - Diastole & $1.88 \pm 0.13$ & $1.91 \pm 0.08$ & 0.869 \\
\hline & Posterior Wall - Systole & $3.33 \pm 0.33$ & $3.45 \pm 0.19$ & 0.756 \\
\hline \multicolumn{5}{|l|}{ Function } \\
\hline & $\mathbf{E F}(\%)$ & $76.32 \pm 7.53$ & $77.55 \pm 4.21$ & 0.892 \\
\hline & FS $(\%)$ & $49.51 \pm 8.19$ & $48.84 \pm 4.18$ & 0.944 \\
\hline & $\mathbf{S V}(\boldsymbol{\mu l})$ & $842.76 \pm 66.50$ & $682.77 \pm 124.06$ & 0.299 \\
\hline & $\mathrm{SV} / \mathrm{BW}(\boldsymbol{\mu l} / \mathbf{k g})$ & $1241.26 \pm 115.79$ & $1069.57 \pm 137.08$ & 0.376 \\
\hline & Heart Rate (BPM) & $362.50 \pm 18.96$ & $399.00 \pm 8.08$ & 0.18 \\
\hline & $\mathrm{CO}(\mu \mathrm{l} / \mathrm{min})$ & $294.36 \pm 29.13$ & $258.79 \pm 41.65$ & 0.510 \\
\hline & $\mathrm{CO} / \mathrm{BW}(\mu \mathrm{l} / \mathrm{min} / \mathbf{k g})$ & $431.58 \pm 43.44$ & $407.14 \pm 44.75$ & 0.709 \\
\hline \multicolumn{5}{|c|}{ Measure of Post-ischaemic Damage } \\
\hline & CK-MB (IU/L) & $443.5 \pm 18.7$ & $460.7 \pm 22.8$ & 0.574 \\
\hline
\end{tabular}

$\mathrm{EF}$ - ejection fraction, FS - fractional shortening, SV - stroke volume, BW - bodyweight, $\mathrm{CO}$ - cardiac output, $\mathrm{CK}-\mathrm{MB}$ - creatine kinase (muscle/brain) 
Table 4. Markers of Liver Function

$\begin{array}{cccc} & \frac{\text { CTRL }}{(\boldsymbol{n}=\mathbf{5})} & \frac{\text { TREN }}{(\boldsymbol{n}=\mathbf{5})} & \boldsymbol{p} \\ \text { AST (IU/L) } & 488.23 \pm 47.03 & 505.67 \pm 46.10 & 0.801 \\ \text { ALT (IU/L) } & 71.76 \pm 8.61 & 73.84 \pm 10.52 & 0.882 \\ \text { ALP (IU/L) } & 40.57 \pm 2.24 & 32.04 \pm 4.28 & 0.116 \\ \text { Albumin (g/L) } & 14.72 \pm 0.78 & 16.75 \pm 0.92 & 0.135\end{array}$

AST - aspartate aminotransferase, ALT - alanine aminotransferase, ALP - alkaline phosphatase 


\section{FIGURES}
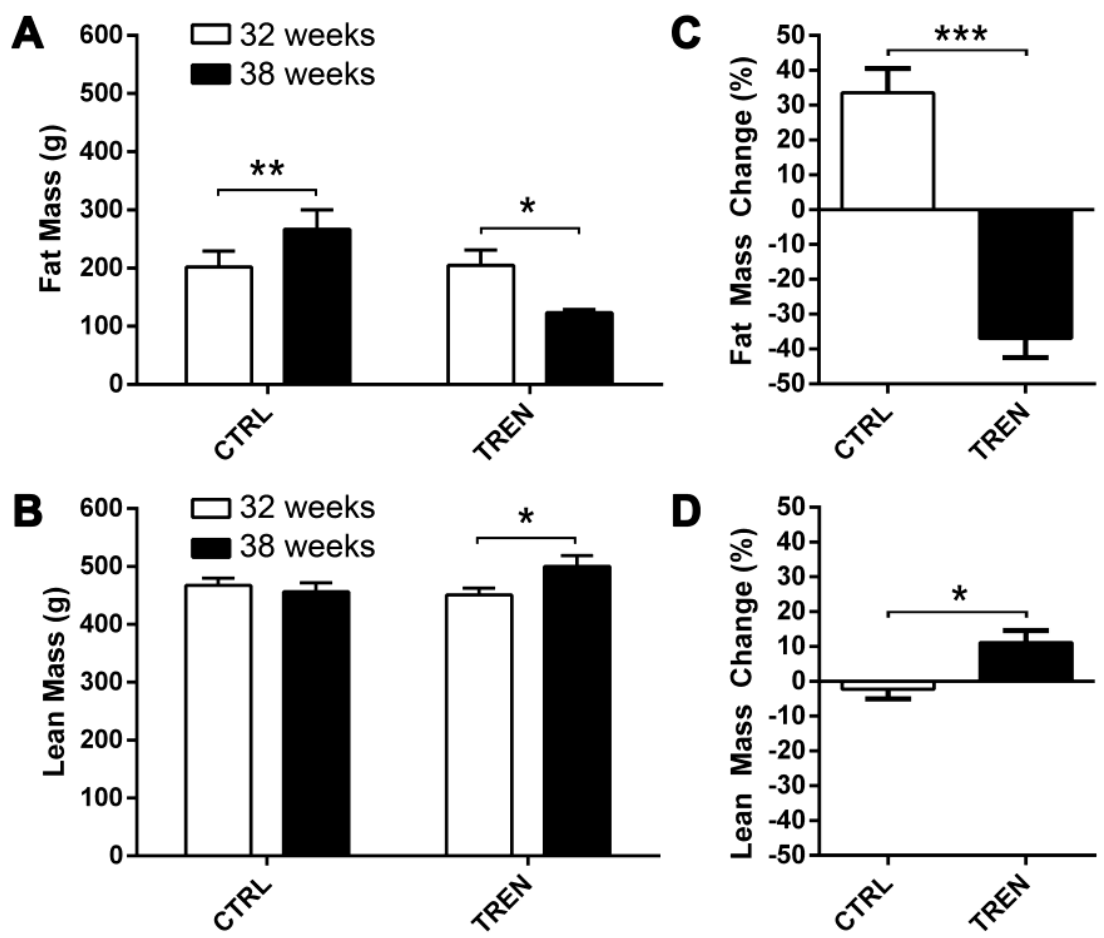

Figure 1. Fat and lean mass changes: A. Fat mass; and B. lean mass at 32 weeks and 38 weeks of age as quantified by DXA. C. Fat mass; and D. lean mass change between DXA scans (38 vs. 32 weeks of age). CTRL - control rats, TREN - trenbolone treated rats. Each value represents mean $\pm \mathrm{SEM}, \mathrm{n}=6, * \mathrm{p}<0.05, * * \mathrm{p}<0.01$, *** $\mathrm{p}<0.001$ 

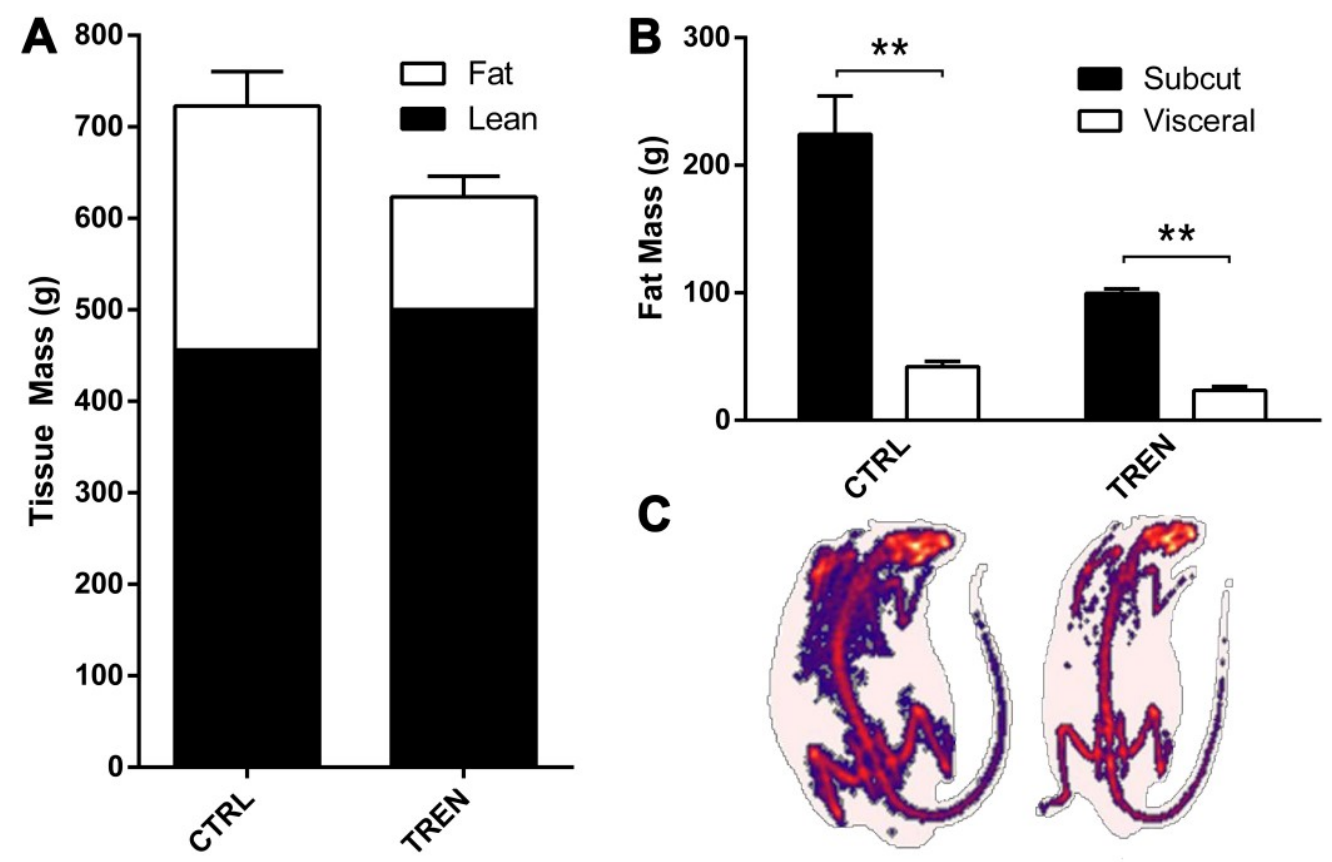

Figure 2. Post-treatment body composition and fat distribution: A. Total body mass at 38 weeks of age delineating body composition. Error bars represent the SEM for total body mass in each group. B. Fat distribution across both subcutaneous (subcut) and visceral depots. C. Representative DXA images of CTRL and TREN rats. CTRL - control rats, TREN trenbolone treated rats. Each value represents mean \pm SEM, $n=6, * p<0.05, * * * p<0.001$ 

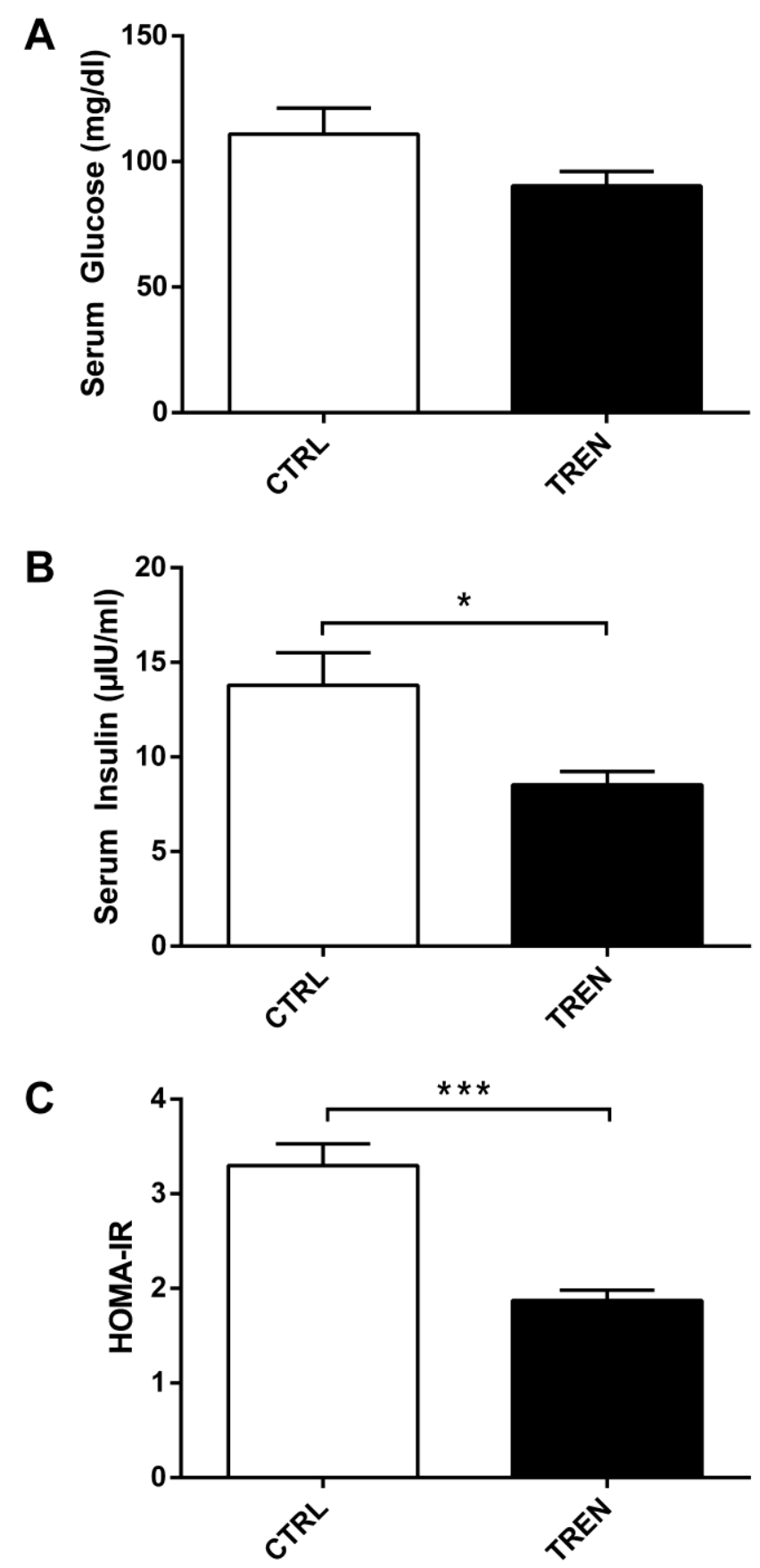

Figure 3. Indices of insulin sensitivity: A. Serum glucose concentrations (mg/dl). B. Serum insulin concentrations $(\mu \mathrm{IU} / \mathrm{ml})$. C. Homeostatic model assessment of insulin resistance (HOMA-IR) (values are arbitrary). CTRL - control rats, TREN - trenbolone treated. Each value represents mean $\pm \mathrm{SEM}, n=5, * * \mathrm{p}<0.01, * * * \mathrm{p}<0.001$ 

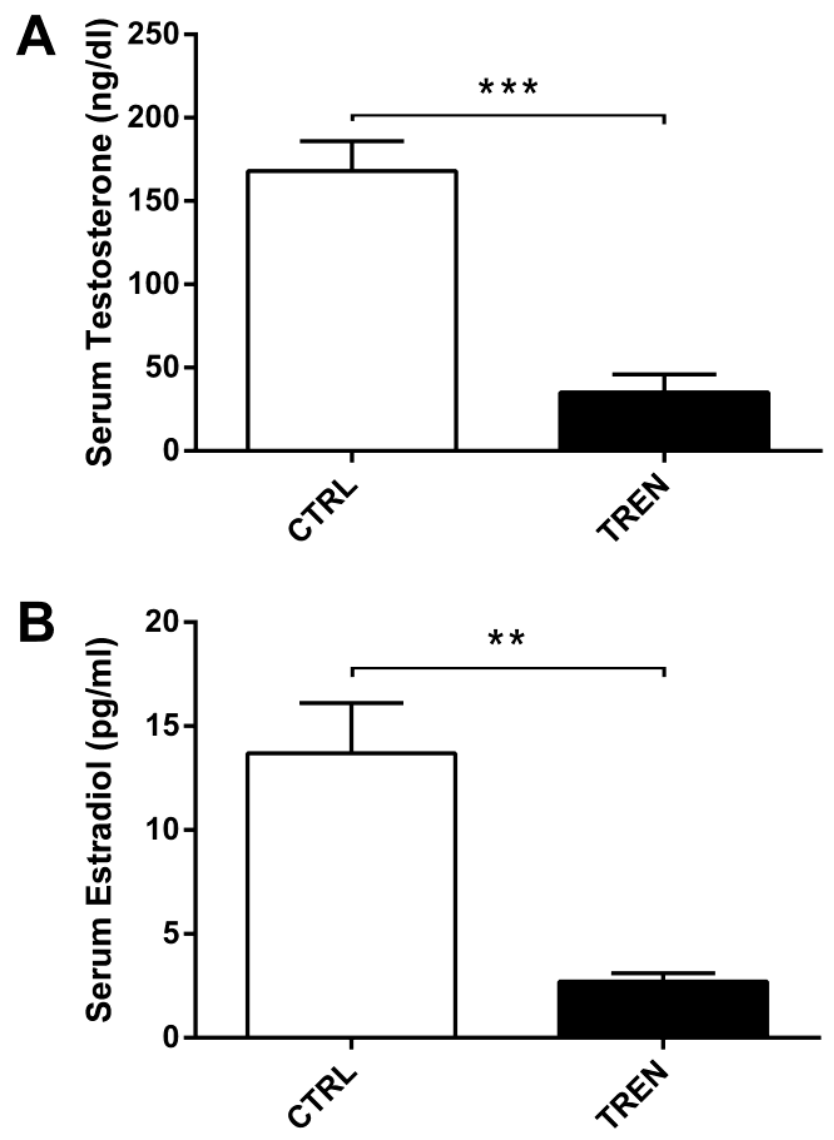

Figure 4. Circulating sex hormones: Serum concentrations of A. testosterone (ng/dl); and B. estradiol (pg/ml). CTRL - control rats, TREN - trenbolone treated.. Each value represents mean \pm SEM, $n=6,{ }^{*} \mathrm{p}<0.05, * * \mathrm{p}<0.01, * * * \mathrm{p}<0.001$ 

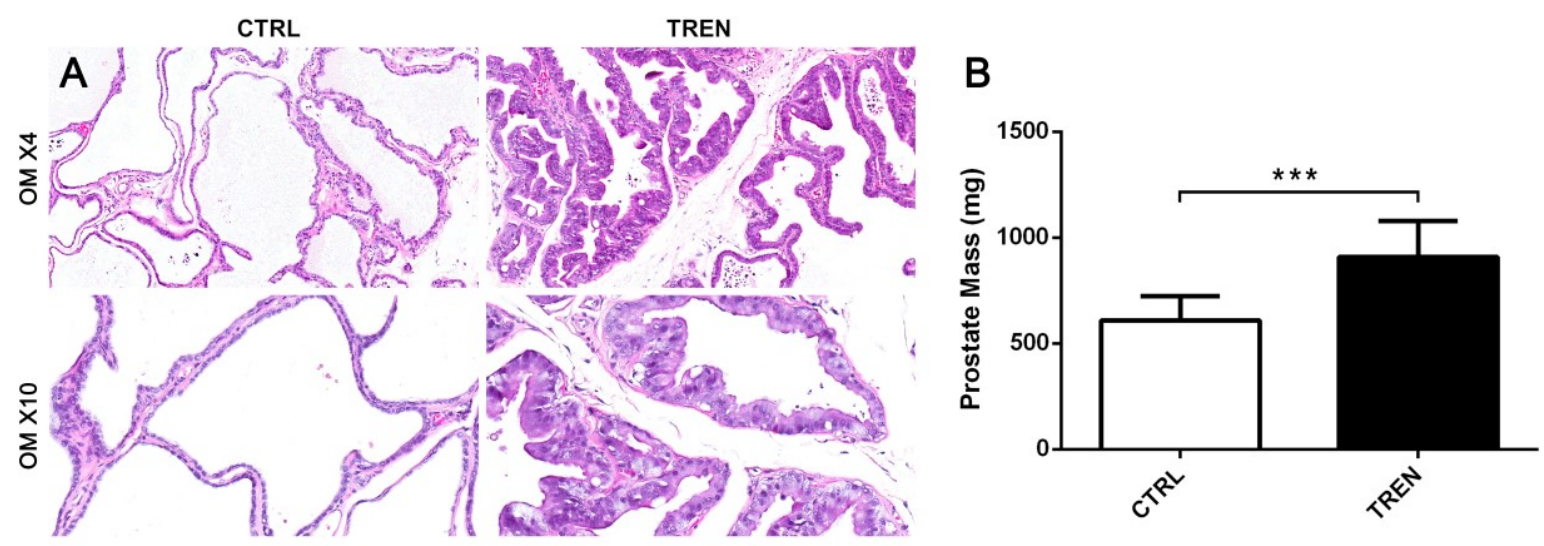

Figure 5. Prostate histology and wet mass: A. Prostates from CTRL rats revealing unremarkable histology with glands lined by two thin layers of cuboidal cells. Hyperplastic prostates from TREN-treated rats showing glands with proliferative changes evidenced by two layers of columnar cells consistent with nodular hyperplasia and not carcinoma (HE). B. Wet mass of prostates excised at sacrifice. OM - original magnification, CTRL - control rats, TREN - trenbolone treated. Each value represents mean \pm SEM, $n=6$, *** $\mathrm{p}<0.001$ 


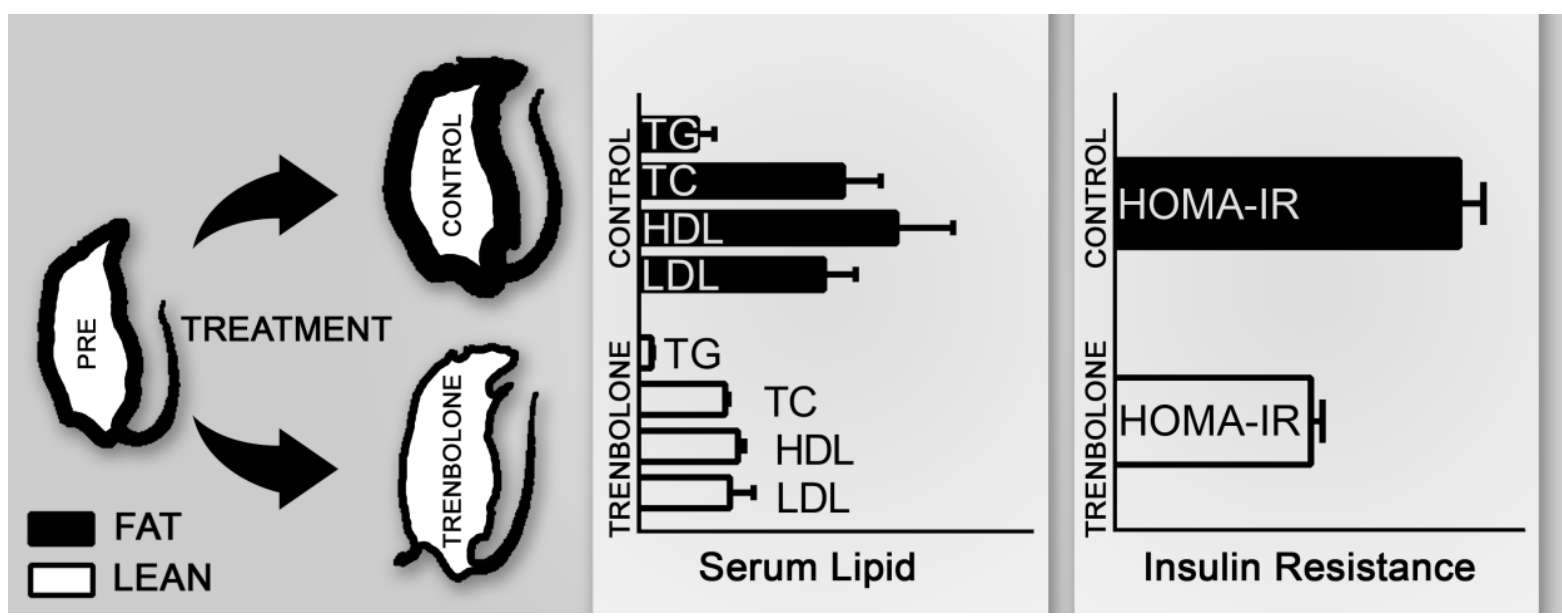

Graphical abstract 